RUNNING HEAD: Organ donation myths

\title{
Do the myths still exist? Revisiting people's negative beliefs about organ donation upon death
}

\author{
Melissa K. Hyde, Kylie R. Wihardjo, and Katherine M. White
}

School of Psychology and Counselling, Institute of Health and Biomedical Innovation, Queensland University of Technology, Kelvin Grove, Queensland, 4059. Australia.

Keywords: organ donation upon death, attitudes, beliefs

Abstract word count: 102

Text word count: 2856

Tables and Figures: 3 Tables

Correspondence concerning this article should be addressed to: Dr Melissa Hyde, School of Psychology and Counselling, Queensland University of Technology, Victoria Park Road, Kelvin Grove, Queensland, 4059, Australia. Telephone: +61 73138 4887. Fax: +61 73138 0486. Email: mk.hyde@qut.edu.au

\section{Acknowledgements}

This study was supported by a Queensland University of Technology, Faculty of Health, Vacation Research Experience Scheme grant to the first and second author. The authors have no conflicts of interest to declare. 


\begin{abstract}
The prevalence of myths preventing people partial to donation in Australia from consenting is unknown. Respondents ( $\mathrm{N}=468: 381$ donors, 26 non-donors, 61 undecided) were surveyed about their (negative) donation beliefs. Approximately $30 \%$ of donors were neutral or supported negative beliefs about organ allocation, especially donation to undesirable organ recipients and a black market organ trade. Confusion about brain death, lack of family and religious support, and discomfort with donation were negative beliefs endorsed by some respondents irrespective of donor preference. Proportionally, donors had greater trust in hospitals/doctors than other groups. Some myths still exist but may vary with donation preference.
\end{abstract}




\section{Do the myths still exist? Revisiting people's negative beliefs about organ donation upon death}

Bridging the gap between organ supply and demand is critical to ensure people whose lives may be saved or improved receive the therapeutic benefits of transplantation. It is well established that Australia has one of the lowest posthumous organ donation rates in the world (13.8 dpmp in 2010) compared to other countries with similar opt-in systems (DonateLife, 2011). The potential to increase organ donation in Australia has been explored in several ways including hospital auditing (Opdam \& Silvester, 2006), alternative donation pathways (e.g., donation after cardiac death) (Richards \& Rogers, 2007), and strategies to increase family consent for donation (Chapman et al., 1995; Mathew, 2004).

Before all of these factors come into play, however, a person must first have the desire to be a donor. At this phase of the decision-making process, a person's beliefs and attitudes play an important role in their chosen donation preference (Radecki \& Jaccard, 1997). Accordingly, numerous international investigations have explored individuals' organ donation beliefs (Nijkamp, Hollestelle, Zeegers, van den Borne, \& Reubsaet, 2008; Radecki \& Jaccard, 1997), including altruistic, (Morgan \& Miller, 2001; Skowronski, 1997) practical, (Sanner, 1994; Skowronski, 1997; Yeung, Kong, \& Lee, 2000) and religious/spiritual (Kececioglu, Tuncer, Yucetin, Akaydin, \& Yakupoglu, 2000; Lam \& McCullough, 2000; Parisi-Rizzo, 1987; Radecki \& Jaccard, 1997; Skowronski, 1997) beliefs encouraging donation. However, many beliefs about organ donation are negative and reflect a lack of knowledge about and discomfort with the donation process.

Prominent among these negative perceptions is the belief that, if a registered donor is in an accident, doctors will not try as hard to save their life or may declare their death prematurely for the purposes of procuring organs (Arriola, Perryman, \& Doldren, 2005; Boulware, Ratner, 
Sosa, Cooper, LaVeist, \& Powe, 2002; Haustein \& Sellers, 2004; Parisi \& Katz, 1986;

Skowronski, 1997). These misconceptions include mistrust in hospitals and the medical system as a reason preventing organ donation, particularly for non-Caucasian populations (Boulware et al., 2002; Fahrenwald \& Stabnow, 2005; Morgan, Harrison, Afifi, Long, \& Stephenson, 2008;

Sanner, 1994). This mistrust extends to beliefs about inequities in the organ allocation process such as wealthy or famous people being more likely to receive a transplant (Haustein \& Sellers, 2004; Morgan et al., 2008) and organs being given to undesirable recipients who are considered to be responsible for their own illness (Haustein \& Sellers, 2004; Hyde \& White, 2009; Morgan et al., 2008; Skowronski, 1997). Although most Western religions support organ donation, needing an intact body for the afterlife and uncertainty about whether a religion permits donation have often been cited as reasons preventing donation (Arriola et al., 2005; Fahrenwald \& Stabnow, 2005; Frates, Bohrer, \& Thomas, 2006; Kececioglu et al., 2000; Lam \& McCullough, 2000). Negative perceptions about organ donation have also been attributed to feelings of discomfort about one's mortality (Alvaro, Jones, Robles, \& Siegel, 2005; Radecki \& Jaccard, 1997; Yeung et al., 2000), fear of not really being dead when organs are procured (Hessing \& Elffers, 1986-87; Kececioglu et al., 2000; Morgan et al., 2008), talking about death as bad luck or a jinx (Frates, Bohrer, \& Thomas, 2006; Morgan et al., 2008), concerns about disfigurement or mutilation (e.g., being 'cut up') (Sanner, 1994; Sque, Payne, \& Clark, 2006), and organ donation as “gross “or “disgusting” (Morgan et al., 2008; Sanner, 2001). Lack of family support for or objection to donation may also contribute to negative beliefs (Alvaro et al., 2005; Boulware et al., 2002; Morgan et al., 2008; Radecki \& Jaccard, 1997; Sanner, 1994).

While numerous negative perceptions about organ donation have been identified, what is less well known is the extent to which these beliefs about organ donation continue to exist for people in the Australian community. Given that there have been few recent studies conducted 
from an Australian perspective, we examined these negative donation perceptions and explored any potential differences in these beliefs in a sample of people who self-identified as donors (want to donate upon death), non-donors (do not want to donate), and undecided (uncertain about donation preference). Understanding people's beliefs about organ donation will provide important information for the transplant community and offer potential targets for intervention to continue to address negative perceptions associated with the donation process and to encourage those partial to donation to strengthen their decision.

\section{Method}

\section{Participants, Design and Procedure}

Australian residents aged 18 years and older $(N=468 ; 369$ female; 381 donors, 26 nondonors, 61 undecided) completed an online survey. Participants were 243 members of the general community (recruited outside of the university context) and 222 students from a south-east Queensland university (3 participants did not identify their status as a student or community member). Table 1 presents demographics for the overall sample and each donor group. Overall, the sample comprised predominantly female (79\%), Caucasian (92\%) participants aged below 35 years $(60.3 \%)$. Approximately half the participants were in a relationship or married (53.4\%) and did not classify themselves as students $(52.4 \%)$. The majority of participants believed they were eligible to donate $(90.4 \%)$. Upon receiving ethical approval, community members were recruited using two methods to increase generalisability of the sample; a postcard inviting participation in the online survey placed in residential mailboxes in south-east Queensland (which provided a low response rate of $16.8 \%$ ), and snowballing via an email invitation to Australian residents (response rate unable to be calculated due to the snowballing method adopted). University students were contacted via email (giving a response rate of $37.5 \%$ based on the number of students contacted 
who were enrolled in a general health communication subject). Participants opted to enter a prize draw to win one of three AUD\$50 music store vouchers.

\section{Measures}

A 50-item survey requested demographics (Table 1), organ donation preference (Table 1), knowledge of the organ donation process (self-reported and 8 true/false questions based on Hyde \& White, 2007) (Table 2), and negative beliefs about organ donation upon death (Table 3).

Initially, we conducted a review of existing research (e.g., Haustein \& Sellers, 2004; Morgan et al., 2008; Parisi-Rizzo, 1987; Radecki \& Jaccard, 1997; Sanner, 1994) and identified six negative belief themes: lack of awareness about organ donation; family issues and consent; discomfort with organ donation; body integrity and religious/spiritual; organ allocation; mortality and mistrust of doctors/medical system. Questions from existing research corresponding to these themes were then chosen. Responses to belief statements were coded for analyses as Disagree (comprising somewhat disagree, disagree, and strongly disagree responses), Neither (neither agree nor disagree), and Agree (comprising somewhat agree, agree, and strongly agree responses).

\section{Results and Discussion}

Overall, the exploratory results of the study (Tables 2 and 3) suggest that, in this study, some myths do still exist. Knowledge deficits identified in the literature two decades ago (e.g., Horton \& Horton, 1990) were still evident in the sample studied. This study demonstrates that there may be some key differences in beliefs between donors, non-donors, and those undecided about their organ donation decision and underscores the importance of examining these groups separately to avoid obscuring important findings. It is important to consider also that participants in this study self-identified as donors, non-donors, and undecided about donation and may or may not have communicated their donation preference on a register or to family. For donors, 
particularly, it is critical to identify those myths that may be preventing people who want to or are considering donating from acting on their preference by communicating it to others.

\section{Knowledge and lack of awareness about organ donation}

While donor and non-donor groups rated their knowledge about organ donation as average or above, $36.1 \%$ of the undecided respondents felt their knowledge was below average and $53.1 \%$ did not know enough about organ donation to make a decision. Undecided respondents, therefore, may benefit most from efforts to increase general knowledge about organ donation. Regardless of donation preference, the majority of donor (58.9\%) and undecided $(62.3 \%)$ respondents and half of non-donor respondents falsely believed that most Western religious groups do not support the concept of organ donation. Similarly, 55.9\% of donor, 56.6\% undecided, and $50 \%$ of non-donor respondents incorrectly classified the statement that in most cases organs can only be donated if a person has died in an intensive care unit under special circumstance (e.g., brain death), as false. Along with non-donor and undecided respondents, some donors appeared to be confused about the concept of brain death with $14.7 \%$ believing that the definition given for brain death was false (when it was in fact true). In addition, approximately $1 / 3$ of donors were neutral $(22.1 \%)$ or agreed $(9.8 \%)$ that a person who has been declared brain dead could still recover. Future research could identify the aspects of organ donation people feel they need more knowledge about to better meet their information needs.

\section{Family issues and consent}

Family also appeared to be a factor in all respondents' donation preference, especially for donors. $77 \%$ of donors (compared to $20.0 \%$ non-donor and $24.5 \%$ undecided respondents) believed that organ donation would not create distress for their family, and $85.1 \%$ of donors (compared to $15.0 \%$ non-donor and $41.5 \%$ undecided respondents) agreed that their family supported the idea of organ donation. The majority of respondents in all donor groups believed 
that family members would respect their wishes if they were recorded on the register $(90.4 \%$ donor, $80.0 \%$ non-donor, and $60.3 \%$ undecided respondents). Together, these results suggest the importance of encouraging people to consider organ donation as a family, rather than an individual, decision. In this way, regardless of donation preference, respondents will be more confident of family support for organ donation, and making organ donation a family decision will encourage discussion and awareness of loved one's donation wishes which are important factors in the consent process for donation (DeJong et al., 1998).

\section{Discomfort with organ donation}

Fewer donors (15.0\%) agreed with the statements 'organ donation is not natural' (compared to $33.3 \%$ non-donor and $26.1 \%$ undecided respondents) and 'the surest way to bring about one's own death is to make plans for it like registering or talking about their organ donation decision' (4.5\% donor vs. $10.5 \%$ non-donor and $17.0 \%$ undecided respondents). It has been widely lamented in the organ donation literature that most people think organ donation is valuable yet there is a discrepancy between attitudes and behaviour (Radecki \& Jaccard, 1997). Most donors (79.3\%) were not uncomfortable with the idea of donating their organs. In comparison, non-donor and undecided respondents supported the idea of organ donation in principle but did not like the thought of donating their own organs (79.0\% non-donor, $61.7 \%$ undecided) and agreed that the idea of donating organs upon their death made them feel uncomfortable (85.0\% non-donor, $64.1 \%$ undecided). Clearly, a beneficial strategy would be to assist people who may be partial to donation (i.e., undecided) to overcome their discomfort about organ donation. Such strategies may be informed by research in the blood donation context which aims to assist potential and new donors to overcome their anxiety about donating blood (Armitage \& Reidy, 2008; France, Montalva, France, \& Trost, 2008).

\section{Body integrity and Religious/Spiritual}


Most donors either disagreed with (67.9\%) or were impartial to $(20.2 \%)$ considering organ donation as having religious or spiritual meaning. However, across all donor groups, a small percentage of respondents indicated that organ donation did have religious/spiritual meaning (11.9\% donor, $36.9 \%$ non-donor, $10.6 \%$ undecided) and their religious beliefs (1.5\% donor, $20.0 \%$ non-donor, $3.8 \%$ undecided $)$ and need to maintain body integrity after death $(2.1 \%$ donor, $21.1 \%$ non-donor, $8.5 \%$ undecided) may prevent them from donating. This finding, coupled with a lack of awareness of the support of Western religious denominations for organ donation, suggests that involving religious leaders in the promotion of organ donation as a valued and accepted practice for Western religious affiliations may encourage some people considering donation to strengthen their commitment (Arriola, Perryman, Doldren, Warren, \& Robinson, 2007).

\section{Organ allocation}

Compared to other negative beliefs/myths explored in this study, donors were more likely to endorse misconceptions related to organ allocation, especially beliefs suggesting there is bias in the organ allocation system. In particular, some donors believed that giving a liver transplant to someone who has abused alcohol or drugs is unethical (18.2\% agree, $19.7 \%$ neutral) and there is a black market trade in organs (11.0\% agree, $31.4 \%$ neutral). These myths were similarly supported in comparatively greater numbers by non-donor and undecided respondents. Approximately half of undecided and non-donor respondents were neutral about or agreed with the statements that wealthy people and celebrities are moved to the top of the list faster than regular people for transplants (52.7\% non-donor, $57.5 \%$ undecided), racial discrimination prevents people from receiving the transplants they need (63.1\% non-donor, $48.9 \%$ undecided), and that their organs might be placed into an undesirable person $(52.6 \%$ non-donor, $72.4 \%$ undecided). The neutral or positive support for these beliefs may reflect controversial instances 
promoted by the media (Quick et al., 2007) such as the recent case involving the young mother who was denied a second transplant after her first transplant failed due to continued drug use. Alternatively, endorsement of these beliefs could be due to a lack of awareness about the process of organ allocation to recipients in Australia (Hyde \& White, 2009).

\section{Mortality and Mistrust of doctors/medical system}

A smaller proportion of donor respondents in this study agreed with the belief statements about mortality. $13.6 \%$ of donors were neutral or agreed with the statement that they were scared they would not really be dead when organs are procured. $25.4 \%$ of donors were neutral or agreed they avoid thinking about donation because they don't like thinking of their death. Donors had much greater levels of trust in the medical system compared to non-donor and undecided respondents. Specifically, more non-donor and undecided respondents agreed that, if they were in an accident and doctors knew of their donor status, the doctors would not try as hard to save their life (30.0\% non-donor, $28.3 \%$ undecided). Furthermore, $52.6 \%$ of non-donor and $21.2 \%$ of undecided respondents did not trust hospitals or doctors. However, 6.9\% of donors still reported mistrusting doctors and/or the medical system, suggesting that for some people in this study, mistrust in the medical system and a preference to be a donor were not mutually exclusive. Such reluctance to donate due to fears or discomfort about death or a premature end to life to facilitate the organ donation process may prevent those partial to donation from acting on their wishes by registering (Siegel, Alvaro, Crano, Gonzalez, Tang, \& Jones, 2010), ultimately resulting in low rates of registration.

These findings coupled with the deficits identified in knowledge about brain death offer a potentially unique insight. It is often assumed that the belief in recovery from a brain death diagnosis is due to misunderstanding the concept of brain death (DeJong et al., 1998; Siminoff, Burant, \& Youngner, 2004); however, in this study, considering that a reasonable proportion of 
respondents in all donor groups reported a lack of trust for doctors and hospitals and feared that they won't really be dead when organs are procured suggests that these respondents do not have confidence in medical professionals' ability to diagnose death. Qualitative research may assist in exploring and further clarifying people's reasons for their beliefs about recovery from brain death as either a lack of knowledge or another expression of people's mistrust in the medical/transplantation system.

\section{Conclusion}

In drawing conclusions we are limited by the small numbers of non-donor and undecided respondents, the focus on primarily Caucasian and female participants (potentially reflecting the self-selection of these two populations into the study given their greater willingness to donate; e.g., Perkins, 1987), and the use of descriptive results. While the percentage of donor (81.4\%), undecided (13.0\%) and non-donor (5.6\%) participants in this study are consistent with percentages reported in previous Australian survey research (e.g., 94\% support, 5\% neither support nor oppose, $1 \%$ oppose donation; Campbell Research \& Consulting, 2006), the male to female ratio and predominantly Caucasian sample is not, thus limiting the generalisability of the results to the broader Australian population. However, several key areas were highlighted that require further exploration. For donors, particularly, the myths subscribed to related more to misconceptions about the organ allocation process and confusion surrounding the concept of brain death. Beliefs related to family and religious support and discomfort with donation were also important considerations for a sizeable proportion of respondents in all donor groups. Although not generalisable to the Australian community as a whole, these results still offer important insights for the transplant and health community and may suggest useful targets for future interventions designed to reduce the prevalence of myths and negative beliefs about organ donation. For example, regardless of donation preference, it was evident that there were concerns 
related to the recipients of organs and the way in which these organs were distributed. Future interventions to address misconceptions related to the organ transplant process are needed including the provision of more transparent organ allocation guidelines and community education about the organ allocation process. Challenging donation myths can potentially lead to people's positive reassessment of their decision against, or indecision about, becoming an organ donor. Ultimately, overcoming such myths will help to strengthen organ donation decisions by communicating consent on a donor register or to family, essential elements of the organ donation process. 


\section{References}

Alvaro, E. M., Jones, S. P., Robles, A. S. M., \& Siegel, J. T. (2005). Predictors of organ donation behaviour among Hispanic Americans. Progress in Transplantation, 15, 149-156.

Armitage, C. J., \& Reidy, J. G. (2008). Use of mental simulations to change theory of planned behaviour variables. British Journal of Health Psychology, 13, 513-524. DOI: $10.1348 / 135910707 \times 227088$

Arriola, K. R., Perryman, J. P., \& Doldren, M. (2005). Moving beyond attitudinal barriers: Understanding African Americans' support for organ and tissue donation. Journal of the National Medical Association, 97, 339-350.

Boulware, L. E., Ratner, L. E., Cooper, L. A., Sosa, J. A., La Veist, T. A., \& Powe, N. R. (2002). Understanding disparities in donor behavior: Race and gender differences in willingness to donate blood and cadaveric organs. Medical Care, 40(2), 85-95.

Campbell Research \& Consulting. (2006). Community perceptions on organ and tissue donation

for transplantation: Final report, Australians Donate. Victoria, Australia: Campbell Research \& Consulting Pty Ltd.

Chapman, J. R., Hibberd, A. D., McCosker, C., Thompson, J. F., Ross, W., Mahony, J., et al.

(1995). Obtaining consent for organ donation in nine NSW metropolitan hospitals. Anaesthesia and Intensive Care, 23, 81-87.

DeJong, W., Franz, H. G., Wolfe, S. M., Nathan, H., Payne, D., Reitsma, W., et al. (1998). Requesting organ donation: An interview study of donor and nondonor families. American Journal of Critical Care, 7, 13-23.

DonateLife. (2011). Facts \& statistics. DonateLife. Retrieved $20^{\text {th }}$ February, 2011 from http://www.donatelife.gov.au/Discover/Facts-and-Statistics.html

Fahrenwald, N. L., \& Stabnow, W. (2005). Sociocultural perspective on organ and tissue 
donation among reservation-dwelling American Indian adults. Ethnicity and Health, 10, 341-354. DOI: 10.1080/10810730600934542

France, C. R., Montalva, R., France, J. L., \& Trost, Z. (2008). Enhancing attitudes and intentions in prospective blood donors: evaluation of a new donor recruitment brochure. Transfusion, 48, 526-530. DOI: 10.1111/j.1537-2995.2007.01565.x

Frates, J., Bohrer, G. G., \& Thomas, D. (2006). Promoting organ donation to Hispanics: The role of the media and medicine. Journal of Health Communication, 11, 683-698. DOI: $10.1080 / 13557850500168826$

Haustein, S. V., \& Sellers, M. T. (2004). Factors associated with (un)willingness to be an organ donor: Importance of public exposure and knowledge. Clinical Transplantation, 18, 193200. DOI: 10.1046/j.1399-0012.2003.00155.x

Hessing, D. J., \& Elffers, H. (1986-87). Attitude toward death, fear of being declared dead too soon, and donation of organs after death. Omega, 17, 115-126.

Horton, R. L., \& Horton, P. J. (1990). Knowledge regarding organ donation: Identifying and Overcoming barriers to organ donation. Social Science and Medicine, 31, 791-800.

Hyde, M. K., \& White, K. M. (2007). Young Australian adults' knowledge and beliefs about organ donation. Progress in Transplantation, 17, 220-227.

Hyde, M. K., \& White, K. M. (2009). Student and community perceptions about organ donors, non-donors and transplant recipients. Journal of Community and Applied Social Psychology, 19, 125-141. DOI: 10.1002/casp.979

Kececioglu, N., Tuncer, M., Yucetin, L., Akaydin, M., \& Yakupoglu, G. (2000). Attitudes of religious people in Turkey regarding organ donation and transplantation. Transplantation Proceedings, 32, 629-630. DOI: 10.1016/S0041-1345(00)00923-4

Lam, W. A., \& McCullough, L. B. (2000). Influence of religious and spiritual values on the 
willingness of Chinese-Americans to donate organs for transplantation. Clinical Transplantation, 14, 449-456. DOI: 10.1034/j.1399-0012.2000.140502.x

Mathew, T. (2004). The Australian experience in organ donation - 2003. Annals of Transplantation, 9, 28-30.

Morgan, S. E., \& Miller, J. K. (2001). Beyond the organ donor card: The effect of knowledge, attitudes, and values on willingness to communicate about organ donation with family members. Health Communication, 14, 121-134. DOI: 10.1207/S15327027HC1401_6

Morgan, S. E., Harrison, T. R., Afifi, W. A., Long, S. D., \& Stephenson, M. T. (2008). In their own words: The reasons why people will (not) sign an organ donor card. Health Communication, 23, 23-33. DOI: 10.1080/10410230701805158

Nijkamp, M. D., Hollestelle, M. L., Zeegers, M. P., van den Borne, B., \& Reubsaet, A. (2008). To be(come) or not to be(come) an organ donor, that's the question: A meta-analysis of determinant and intervention studies. Health Psychology Review, 2, 20-40. DOI: $10.1080 / 17437190802307971$

Opdam, H. I., \& Silvester, W. (2006). Potential for organ donation in Victoria: An audit of hospital deaths. Medical Journal of Australia, 185, 250-254.

Parisi, N., \& Katz, I. (1986). Attitudes toward posthumous organ donation and commitment to donate. Health Psychology, 5, 565-580.

Parisi-Rizzo, N. (1987). Relative efficacy of imagery, persuasion, and empathic messages for inducing commitment to posthumous organ donation. Dissertation Abstracts International, 48/06, 8713782 .

Perkins, K. A. (1987). The shortage of cadaver donor organs for transplantation: Can psychology help? American Psychologist, 42, 921-930.

Quick, B. L., Meyer, K. R., Kim, D. K., Taylor, D., Kline, J., Apple, T., et al. (2007). Examining 
the association between media coverage of organ donation and organ transplantation rates. Clinical Transplantation, 21, 219-223. DOI: 10.1111/j.1399-0012.2006.00628.x

Radecki, C. M., \& Jaccard, J. (1997). Psychological aspects of organ donation: A critical review and synthesis of individual and next-of-kin donation decisions. Health Psychology, 16, 183-195.

Richards, B., \& Rogers, W. A. (2007). Organ donation after cardiac death: Legal and ethical justifications for antemortem interventions. Medical Journal of Australia, 187, 168-170.

Sanner, M. A. (1994). A comparison of public attitudes toward autopsy, organ donation, and anatomic dissection. Journal of the American Medical Association, 271, 284-288.

Sanner, M. A. (2001). Exchanging spare parts or becoming a new person? People's attitudes toward receiving and donating organs. Social Science and Medicine, 52, 1491-1499. 427-456. doi:10.1016/S0277-9536(00)00258-6

Siegel, J. T., Alvaro, E. M., Crano, W. D., Gonzalez, A. V., Tang, J. C., \& Jones, S. P. (2010). Passive-positive organ donor registration behavior: A mixed method assessment of the IIFF Model. Psychology, Health \& Medicine, 15, 198-209.

Siminoff, L. A., Burant, C., \& Youngner, S. J. (2004). Death and organ procurement: Public beliefs and attitudes. Social Science \& Medicine, 59, 2325-2334. doi:10.1016/j.socscimed.2004.03.029

Skowronski, J. J. (1997). On the psychology of organ donation: Attitudinal and situational factors related to the willingness to be an organ donor. Basic and Applied Social Psychology, 19,

Sque, M., Payne, S. A., \& Clark, J. M. (2006). Gift of life or sacrifice?: Key discourses to understanding organ donor families' decision-making. Mortality, 11, 117-132. DOI: $10.1080 / 13576270600615260$

Yeung, I., Kong, S. H., \& Lee, J. (2000). Attitudes towards organ donation in Hong Kong. Social 
Science and Medicine, 50, 1643-1654. doi:10.1016/S0277-9536(99)00393-7 
Table 1

Participant demographic characteristics according to donor group

\begin{tabular}{|c|c|c|c|c|c|}
\hline & & $\begin{array}{l}\text { Overall } \\
(\mathrm{n}=468) \\
\%\end{array}$ & $\begin{array}{l}\text { Donor } \\
(\mathrm{n}=381) \\
\%\end{array}$ & $\begin{array}{l}\text { Non- } \\
\text { Donor } \\
(\mathrm{n}=26) \\
\%\end{array}$ & $\begin{array}{l}\text { Undecided } \\
(\mathrm{n}=61) \\
\%\end{array}$ \\
\hline \multirow[t]{2}{*}{ Gender } & Male & 21.0 & 21.3 & 30.8 & 14.8 \\
\hline & Female & 79.0 & 78.7 & 69.2 & 85.2 \\
\hline \multirow[t]{8}{*}{ Age } & $18-25$ & 38.5 & 36.0 & 42.3 & 52.5 \\
\hline & $26-35$ & 21.8 & 23.4 & 15.4 & 14.8 \\
\hline & $36-45$ & 12.8 & 12.3 & 7.7 & 18.0 \\
\hline & $46-55$ & 17.3 & 18.1 & 23.1 & 9.8 \\
\hline & $56-65$ & 7.1 & 7.3 & 11.5 & 3.3 \\
\hline & $66-75$ & 1.5 & 1.8 & 0 & 0 \\
\hline & $76-85$ & 0.9 & 1.0 & 0 & 0 \\
\hline & 86 and over & 0.2 & 0 & 0 & 1.6 \\
\hline \multirow[t]{2}{*}{ Ethnicity } & Caucasian & 91.7 & 94.8 & 76.9 & 78.7 \\
\hline & Other & 8.3 & 5.2 & 23.1 & 21.3 \\
\hline \multirow[t]{7}{*}{ Relationship status } & Single & 31.6 & 30.6 & 38.5 & 34.4 \\
\hline & In a relationship & 24.0 & 22.8 & 15.4 & 34.4 \\
\hline & Married & 29.4 & 30.6 & 34.6 & 19.7 \\
\hline & De-facto & 10.0 & 10.5 & 11.5 & 6.6 \\
\hline & Separated & 1.5 & 1.1 & 0 & 4.9 \\
\hline & Divorced & 2.4 & 3.0 & 0 & 0 \\
\hline & Widowed & 1.1 & 1.3 & 0 & 0 \\
\hline \multirow[t]{2}{*}{ Are you a student? } & Yes & 47.7 & 46.7 & 46.2 & 55.0 \\
\hline & No & 52.3 & 53.3 & 53.8 & 45.0 \\
\hline \multirow{2}{*}{$\begin{array}{l}\text { Are there any medical } \\
\text { reasons that you believe } \\
\text { would prevent you from } \\
\text { being a donor? }\end{array}$} & Yes & 9.6 & 8.5 & 31.8 & 7.7 \\
\hline & No & 90.4 & 91.5 & 68.2 & 92.3 \\
\hline
\end{tabular}


Table 2

Participant self-reported knowledge and responses to T/F knowledge questions

\begin{tabular}{|c|c|c|c|c|}
\hline & & $\begin{array}{c}\text { Donor } \\
(\mathrm{n}=381) \\
\%\end{array}$ & $\begin{array}{c}\text { Non- } \\
\text { Donor } \\
(\mathrm{n}=26) \\
\%\end{array}$ & $\begin{array}{l}\text { Undecided } \\
(\mathrm{n}=61) \\
\%\end{array}$ \\
\hline $\begin{array}{l}\text { Overall, how would you rate your knowledge } \\
\text { of the topic of organ donation? }\end{array}$ & $\begin{array}{l}\text { Excellent } \\
\text { Very good } \\
\text { Good } \\
\text { Average } \\
\text { Below average } \\
\text { Poor } \\
\text { Very poor }\end{array}$ & $\begin{array}{r}7.3 \\
18.6 \\
30.7 \\
34.6 \\
5.0 \\
2.6 \\
1.0\end{array}$ & $\begin{array}{r}8.0 \\
20.0 \\
16.0 \\
44.0 \\
4.0 \\
8.0 \\
0\end{array}$ & $\begin{array}{r}1.6 \\
6.6 \\
14.8 \\
41.0 \\
24.6 \\
4.9 \\
6.6\end{array}$ \\
\hline $\begin{array}{l}\text { Almost all Western religious groups support } \\
\text { the concept of organ donation. }\end{array}$ & $\begin{array}{l}\text { True } \\
\text { False }\end{array}$ & $\begin{array}{l}41.1 \\
58.9\end{array}$ & $\begin{array}{l}50.0 \\
50.0\end{array}$ & $\begin{array}{l}37.7 \\
62.3\end{array}$ \\
\hline $\begin{array}{l}\text { In most cases, organs (heart, lungs, liver, } \\
\text { pancreas, kidneys) can only be donated if a } \\
\text { person has died in an intensive care unit } \\
\text { under special circumstances (e.g., brain } \\
\text { death). }\end{array}$ & $\begin{array}{l}\text { True } \\
\text { False }\end{array}$ & $\begin{array}{l}44.1 \\
55.9\end{array}$ & $\begin{array}{l}50.0 \\
50.0\end{array}$ & $\begin{array}{l}43.4 \\
56.6\end{array}$ \\
\hline $\begin{array}{l}\text { Once registered on the Australian Organ } \\
\text { Donor Register, your consent to donate } \\
\text { cannot be revoked. }\end{array}$ & $\begin{array}{l}\text { True } \\
\text { False }\end{array}$ & $\begin{array}{r}6.9 \\
93.1\end{array}$ & $\begin{array}{l}22.7 \\
77.3\end{array}$ & $\begin{array}{r}5.7 \\
94.3\end{array}$ \\
\hline $\begin{array}{l}\text { A greater number of people have the } \\
\text { opportunity to donate tissue for } \\
\text { transplantation (corneas) than organs (e.g., } \\
\text { heart). }\end{array}$ & $\begin{array}{l}\text { True } \\
\text { False }\end{array}$ & $\begin{array}{l}81.2 \\
18.8\end{array}$ & $\begin{array}{l}68.2 \\
31.8\end{array}$ & $\begin{array}{l}79.2 \\
20.8\end{array}$ \\
\hline $\begin{array}{l}\text { The donors' family are responsible for the } \\
\text { hospital and surgery costs for removing, } \\
\text { preserving, and transplanting the donors' } \\
\text { organs. }\end{array}$ & $\begin{array}{l}\text { True } \\
\text { False }\end{array}$ & $\begin{array}{r}4.4 \\
95.6\end{array}$ & $\begin{array}{l}18.2 \\
81.8\end{array}$ & $\begin{array}{r}7.5 \\
92.5\end{array}$ \\
\hline $\begin{array}{l}\text { The potential donor has complete choice } \\
\text { over which organs and tissue they are } \\
\text { prepared to donate. }\end{array}$ & $\begin{array}{l}\text { True } \\
\text { False }\end{array}$ & $\begin{array}{l}82.6 \\
17.4\end{array}$ & $\begin{array}{l}81.8 \\
18.2\end{array}$ & $\begin{array}{l}79.2 \\
20.8\end{array}$ \\
\hline $\begin{array}{l}\text { Anyone over the age of } 40 \text { is not } \\
\text { acceptable as an organ donor. }\end{array}$ & $\begin{array}{l}\text { True } \\
\text { False }\end{array}$ & $\begin{array}{r}4.4 \\
95.6\end{array}$ & $\begin{array}{r}4.5 \\
95.5\end{array}$ & $\begin{array}{r}1.9 \\
98.1\end{array}$ \\
\hline Brain death occurs where there is & True & 85.3 & 90.9 & 92.3 \\
\hline
\end{tabular}


irreversible cessation of all functions of

False

14.7

9.1

7.7

the entire brain including the brain stem. 
Table 3

Participant responses to the negative belief statements about organ donation

\begin{tabular}{|c|c|c|c|c|}
\hline & & $\begin{array}{c}\text { Donor } \\
(\mathrm{n}=381) \\
\%\end{array}$ & $\begin{array}{c}\text { Non-Donor } \\
(\mathrm{n}=26) \\
\%\end{array}$ & $\begin{array}{c}\text { Undecided } \\
(\mathrm{n}=61) \\
\%\end{array}$ \\
\hline \multicolumn{5}{|l|}{ Theme: Family issues and consent } \\
\hline \multirow[t]{3}{*}{ My family supports the idea of organ donation* } & Disagree & 5.5 & 45.0 & 7.6 \\
\hline & Neither & 9.3 & 40.0 & 50.9 \\
\hline & Agree & 85.1 & 15.0 & 41.5 \\
\hline \multirow[t]{3}{*}{ If I am an organ donor upon my death it will create distress for my family } & Disagree & 77.0 & 55.0 & 54.7 \\
\hline & Neither & 10.0 & 25.0 & 20.8 \\
\hline & Agree & 13.0 & 20.0 & 24.5 \\
\hline \multirow{3}{*}{$\begin{array}{l}\text { Even if I record my decision to be an organ donor my family will overturn my } \\
\text { decision }\end{array}$} & Disagree & 90.4 & 80.0 & 60.3 \\
\hline & Neither & 7.8 & 10.0 & 34.0 \\
\hline & Agree & 1.8 & 10.0 & 5.7 \\
\hline \multicolumn{5}{|l|}{ Theme: Discomfort with organ donation } \\
\hline \multirow[t]{3}{*}{ The idea of organ donation disgusts me } & Disagree & 99.1 & 63.2 & 70.2 \\
\hline & Neither & 0.3 & 26.3 & 25.5 \\
\hline & Agree & 0.6 & 10.5 & 4.3 \\
\hline \multirow[t]{3}{*}{ Organ donation is not natural } & Disagree & 74.5 & 38.9 & 43.5 \\
\hline & Neither & 10.5 & 27.8 & 30.4 \\
\hline & Agree & 15.0 & 33.3 & 26.1 \\
\hline \multirow[t]{3}{*}{ The idea of donating my organs upon my death makes me feel uncomfortable } & Disagree & 79.3 & 15.0 & 18.9 \\
\hline & Neither & 4.6 & 0 & 17.0 \\
\hline & Agree & 13.0 & 85.0 & 64.1 \\
\hline
\end{tabular}


I support the idea of organ donation in principle but I don't like the thought of

I don't like the thought of my donated organ/s living on in someone else's body

The surest way to bring about my own death is to make plans for it like registering or talking about my organ donation decision

If I receive someone else's organ/s I will take on the characteristics (e.g. likes/ dislikes/ personality) of that person

I don't like the thought of having another person's organ/s transplanted in my body donating my own organs

$\begin{array}{lrrr}\text { Disagree } & 89.5 & 21.0 & 19.1 \\ \text { Neither } & 6.3 & 0 & 19.1 \\ \text { Agree } & 4.2 & 79.0 & 61.7 \\ & & & \\ \text { Disagree } & 94.7 & 63.1 & 50.0 \\ \text { Neither } & 4.1 & 21.1 & 30.4 \\ \text { Agree } & 1.2 & 15.8 & 19.6 \\ & & & \\ \text { Disagree } & 90.4 & 73.7 & 63.9 \\ \text { Neither } & 5.1 & 15.8 & 19.1 \\ \text { Agree } & 4.5 & 10.5 & 17.0 \\ & & & \\ \text { Disagree } & 82.2 & 79.0 & 72.3 \\ \text { Neither } & 10.7 & 10.5 & 25.0 \\ \text { Agree } & 7.1 & 10.5 & 2.1 \\ & & & \\ \text { Disagree } & 82.8 & 47.2 & 40.4 \\ \text { Neither } & 9.5 & 21.1 & 31.9 \\ \text { Agree } & 7.7 & 31.7 & 27.6 \\ \end{array}$

Theme: Body integrity

I believe that my body should be kept whole for burial

Organ donation shows disrespect for the body after death

I am concerned that my body will be disfigured if I donate my organs when I die

$\begin{array}{lrrr}\text { Disagree } & 85.3 & 10.0 & 34.0 \\ \text { Neither } & 9.9 & 5.0 & 41.5 \\ \text { Agree } & 4.8 & 85.0 & 24.6 \\ & & & \\ \text { Disagree } & 94.7 & 65.0 & 63.5 \\ \text { Neither } & 2.0 & 20.0 & 19.2 \\ \text { Agree } & 3.2 & 15.0 & 17.3 \\ & & & \\ \text { Disagree } & 81.7 & 40.0 & 39.6 \\ \text { Neither } & 9.0 & 35.0 & 37.0 \\ \text { Agree } & 9.3 & 25.0 & 22.7\end{array}$


The thought of being cut up or taken apart after I'm gone makes me feel uneasy

$\begin{array}{lrrr}\text { Disagree } & 77.6 & 42.1 & 25.6 \\ \text { Neither } & 5.4 & 10.5 & 19.1 \\ \text { Agree } & 17.0 & 47.4 & 55.3\end{array}$

Theme: Religious/spiritual

My religious beliefs do not allow me to be an organ donor

I consider organ donation to have religious or spiritual meaning

An intact body is needed for life after death

$\begin{array}{lrrr}\text { Disagree } & 95.7 & 60.0 & 66.0 \\ \text { Neither } & 2.9 & 20.0 & 30.2 \\ \text { Agree } & 1.5 & 20.0 & 3.8 \\ & & & \\ \text { Disagree } & 67.9 & 57.8 & 48.9 \\ \text { Neither } & 20.2 & 5.3 & 40.4 \\ \text { Agree } & 11.9 & 36.9 & 10.6 \\ & & & \\ \text { Disagree } & 92.5 & 63.1 & 55.3 \\ \text { Neither } & 5.4 & 15.8 & 36.2 \\ \text { Agree } & 2.1 & 21.1 & 8.5 \\ & & & \end{array}$

Theme: Lack of awareness about organ donation

I don't know enough about organ donation to make a decision

$\begin{array}{lrrr}\text { Disagree } & 87.0 & 57.8 & 34.0 \\ \text { Neither } & 8.3 & 21.1 & 12.8 \\ \text { Agree } & 4.7 & 21.1 & 53.1 \\ & & & \\ \text { Disagree } & 68.2 & 52.6 & 40.4 \\ \text { Neither } & 22.1 & 10.5 & 27.2 \\ \text { Agree } & 9.8 & 36.9 & 31.9 \\ & & & \\ \text { Disagree } & 96.4 & 73.7 & 80.9 \\ \text { Neither } & 2.1 & 10.5 & 8.5 \\ \text { Agree } & 1.5 & 15.3 & 10.6\end{array}$

A person who has been declared 'brain dead' could still recover

If I donate my organs it isn't possible to have a regular funeral service

Agree 1.5 
Theme: Organ allocation

Giving a liver transplant to someone who has abused alcohol or drugs is not ethical

$\begin{array}{lrrr}\text { Disagree } & 62.0 & 35.0 & 33.9 \\ \text { Neither } & 19.7 & 15.0 & 28.3 \\ \text { Agree } & 18.2 & 50.0 & 37.8 \\ & & & \\ \text { Disagree } & 69.3 & 47.4 & 27.6 \\ \text { Neither } & 17.4 & 31.6 & 36.2 \\ \text { Agree } & 13.3 & 21.0 & 36.2 \\ & & & \\ \text { Disagree } & 97.9 & 84.2 & 85.1 \\ \text { Neither } & 1.5 & 10.5 & 12.8 \\ \text { Agree } & 0.6 & 5.3 & 2.1 \\ & & & \\ \text { Disagree } & 68.0 & 47.0 & 42.5 \\ \text { Neither } & 18.0 & 21.1 & 19.1 \\ \text { Agree } & 13.9 & 31.6 & 38.4 \\ & & & \\ \text { Disagree } & 70.2 & 36.9 & 51.0 \\ \text { Neither } & 19.9 & 36.8 & 31.9 \\ \text { Agree } & 9.8 & 26.3 & 17.0 \\ & & & \\ \text { Disagree } & 57.6 & 42.1 & 31.9 \\ \text { Neither } & 31.4 & 36.8 & 48.9 \\ \text { Agree } & 11.0 & 21.1 & 19.1 \\ & & & \\ \text { Disagree } & 63.3 & 16.7 & 42.6 \\ \text { Neither } & 17.4 & 50.0 & 27.7 \\ \text { Agree } & 19.2 & 33.3 & 29.8 \\ & & & \end{array}$

I am concerned that if I agree to donate my organs might be placed into an undesirable person

I would only donate organs to someone of my own race or culture

Wealthy people and celebrities are moved to the top of the list faster than regular people for organ transplants

Racial discrimination prevents people from receiving the transplants they need

Organs for transplant can be bought and sold on the black market in Australia

There are probably many instances in which a person has been heavily drugged then awakens to find he or she has had an organ removed for a black market transplant

Agree

Disagree

86.4

63.1

I am scared that
transplantation

Neither

6.5

15.8

40.4 19.1 


\begin{tabular}{|c|c|c|c|c|}
\hline & Agree & 7.1 & 21.1 & 40.4 \\
\hline There is plenty of time to think about organ donation later & Neither & 12.8 & 31.6 & 31.9 \\
\hline \multirow[t]{2}{*}{ I avoid thinking about organ donation because I don't like thinking of my death } & Disagree & 74.5 & 55.6 & 34.0 \\
\hline & Neither & 11.2 & 5.6 & 17.0 \\
\hline \multicolumn{5}{|l|}{ Theme: Mistrust of doctors/medical system } \\
\hline \multirow[t]{3}{*}{ I trust that doctors and hospitals use donated organs as they are intended to be used* } & Disagree & 2.7 & 10.6 & 8.6 \\
\hline & Neither & 1.8 & 26.3 & 8.5 \\
\hline & Agree & 95.5 & 63.2 & 82.9 \\
\hline \multirow[t]{3}{*}{ I don't trust hospitals or doctors } & Disagree & 83.4 & 31.6 & 46.8 \\
\hline & Neither & 9.6 & 15.8 & 31.9 \\
\hline & Agree & 6.9 & 52.6 & 21.2 \\
\hline
\end{tabular}

* denotes an item using positive wording to explore a negative belief 